\title{
MYCN Gene
}

National Cancer Institute

\section{Source}

National Cancer Institute. MYCN Gene. NCI Thesaurus. Code C18405.

This gene is involved in transcriptional regulation and amplification of this gene is associated with a variety of tumors, most notably neuroblastomas. 